\title{
PENDIDIKAN DAN PELATIHAN MENINGKATKAN KEMAMPUAN PESERTA MENYUSUN LAPORAN KEUANGAN ORGANISASI SOSIAL KEAGAMAAN
}

\author{
Sarwo Edy Handoyo ${ }^{1}$ dan Herlin Tundjung Setijaningsih ${ }^{2}$ \\ ${ }^{1}$ Dosen Jurusan Manajemen, Universitas Tarumanagara Jakarta \\ Email: sarwoh@fe.untar.ac.id \\ ${ }^{2}$ Dosen Jurusan Akuntansi, Universitas Tarumanagara Jakarta \\ Email: herlins@fe.untar.ac.id
}

\begin{abstract}
The Mosque Prosperity Council as a socio-religious organization has a strategic role in the advancement of society. The role played is in the form of carrying out various activities to increase faith and piety for the Muslim community. To carry out various activities, funding support is required. Funding sources mainly come from mosque congregations and generally come from various donors. Funds that have been successfully collected from the public and their use need to be compiled in the form of financial reports so that they can be accounted for to the public transparently. Based on observations and interviews with the board of the Al Barokah Mosque Prosperity Council, Cibodas District, Tangerang City, Banten, financial reports are submitted regularly, namely every Friday in the form of cash balance reports. Reports like this are inadequate because cash balances are not financial statements and only a small part is in the financial statements. The root of the problem is the lack of knowledge of the board about the details of financial reports including their preparation. The solutions offered to target partners of community service activities include education and training on techniques for preparing financial reports. The results show that there is an effect of education and training on increasing the knowledge and skills of participants in preparing financial reports. By carrying out these activities, the socio-religious activities carried out in the mosque can be reported in the form of accountable and transparent financial reports.
\end{abstract}

Keywords: education, training, financial reports

\begin{abstract}
ABSTRAK
Dewan Kemakmuran Masjid sebagai organisasi sosial keagamaan memiliki peran yang strategis bagi kemajuan masyarakat. Peran yang dijalankan dalam bentuk melaksanakan berbagai kegiatan untuk meningkatkan iman dan taqwa bagi masyarakat muslim. Untuk melaksanakan berbagai kegiatan, diperlukan dukungan pendanaan. Sumber pendanaan terutama berasal dari jamaah masjid dan umumnya dapat berasal dari berbagai donatur. Dana yang berhasil dihimpun dari masyarakat serta penggunaannya perlu disusun dalam bentuk laporan keuangan agar dapat dipertanggungjawabkan kepada masyarakat secara transparan. Berdasarkan observasi dan wawancara dengan pengurus Dewan Kemakmuran Masjid Al Barokah, Kecamatan Cibodas, Kota Tangerang Banten, laporan keuangan yang disampaikan secara rutin yaitu setiap hari Jum'at dalam bentuk laporan saldo kas. Laporan seperti ini jelas tidak memadai karena saldo kas bukanlah laporan keuangan dan hanya sebagian kecil yang ada pada laporan keuangan. Akar permasalahannya adalah keterbatasan pengetahuan pengurus tentang seluk beluk laporan keuangan termasuk penyusunannya. Solusi yang ditawarkan kepada mitra sasaran kegiatan pengabdian masyarakat diadakan pendidikan dan pelatihan mengenai teknik penyusunan laporan keuangan. Hasilnya menunjukkan bahwa terdapat pengaruh pendidikan dan pelatihan terhadap meningkatnya pengetahuan dan keterampilan peserta dalam menyusun laporan keuangan. Dengan dilakukan kegiatan tersebut maka kegiatan sosial keagamaan yang dijalankan di masjid tersebut dapat dilaporkan dalam bentuk laporan keuangan yang dapat dipertanggungjawabkan dan transparan.
\end{abstract}

Kata kunci: pendidikan, pelatihan, laporan keuangan

\section{PENDAHULUAN}

Dewan Kemakmuran Masjid sebagai organisasi sosial keagamaan memiliki orientasi sosial, berperan penting dalam mencerdaskan kehidupan bangsa sebagaimana yang diamanatkan dalam pembukaan UUD 1945. Keberadaannya di Indonesia membantu negara untuk memfasilitasi masyarakat muslim untuk melaksanakan nilai-nilai Pancasila. Masjid memiliki fungsi utama sebagai tempat beribadah sebagai perwujudan pelaksanaan sila pertama yaitu: "Ketuhanan Yang Maha Esa". Namun keberadaan masjid juga dapat berfungsi untuk memfasilitasi anggota masyarakat melaksanakan nilai-nilai kemanusiaan, persatuan, musyawarah maupun keadilan sosial yang tercantum dalam keempat sila lainnya dalam Pancasila. 
Berbagai program kegiatan yang dilakukan di masjid dikategorikan dan dimaksudkan sebagai kegiatan ibadah dalam rangka pengabdian manusia kepada Sang Pencipta Allah S.W.T. Kegiatan ibadah dapat dikelompokkan menjadi dua, yaitu dalam hubungannya dengan Allah (hablum minallah) dan dalam hubungannya dengan manusia (hablum minannas). Kegiatan hablum minallah dapat berupa pelaksanaan sholat baik yang terkait sholat wajib maupun sunnah. Kegiatan hablum minannas terkait dengan hubungannya sesama manusia dalam bermasyarakat, seperti mengumpulkan, memanfaatkan, membagi: zakat, infaq, shodaqoh maupun amal jariyah lainnya. Disamping itu terdapat juga berbagai kegiatan yang menunjang dua kegiatan tersebut seperti pendidikan maupun pengajian.

Kegiatan masjid diarahkan untuk meningkatkan iman dan taqwa para jamaahnya. Iman dalam arti kaum muslim percaya kepada Allah, malaikat, kitab suci, rasul, hari kiamat, serta takdir baik maupun buruk. Taqwa dalam arti menjalankan semua perintah Allah dan menjauhi segala larangannya. Kadar iman dan taqwa manusia mengalami pasang maupun surut. Untuk mencegah surutnya iman dan taqwa serta untuk meningkatkan kadar iman dan taqwa diperlukan berbagai kegiatan yang berkualitas dengan kuantitas yang mencukupi. Disamping itu, terdapat berbagai permasalahan yang dihadapi oleh para jamaah masjid di luar iman dan taqwa. Keberadaan masjid diharapkan memberi kontribusi terhadap pemecahan berbagai masalah yang dihadapi oleh masyarakat sekitarnya. Masjid memiliki peran untuk memberi cahaya bagi masyarakat sekitarnya. Bentuk perannya dapat membantu masyarakat keluar dari kondisi gelap gulita menuju harapan terang benderang dalam menjalani kehidupan. Hal itu dimungkinkan jika masjid menjalankan berbagai kegiatan yang mengarah pada peran utamanya tersebut.

Pada umumnya lembaga masjid dimiliki oleh masyarakat yaitu umat muslim. Pendiriannya dilakukan oleh orang-orang yang mewakafkan hartanya untuk pembangunan masjid. Setelah masjid berdiri dan beroperasi, maka sumber pendapatannya juga berasal dari jamaah masjid (masyarakat muslim), bisa dalam bentuk infaq, shodaqoh, zakat, maupun sumber lain. Oleh karena pendirian dan pemanfaatannya dilakukan oleh masyarakat maka manajemen masjid harus transparan dan akuntabel atau dapat dipertanggungjawabkan kepada masyarakat. Bentuk transparansi dan akuntabilitas semua kegiatan masjid dapat diringkas dalam bentuk laporan keuangan.

Masjid merupakan lembaga nirlaba. Di Indonesia, lembaga nirlaba pelaporan keuangannya diatur dalam PSAK Nomor 45 tentang pelaporan keuangan entitas nirlaba. PSAK ini telah disahkan oleh Dewan Standar Akuntansi Keuangan pada tanggal 8 April 2011. Tujuan laporan keuangan dalam organisasi nirlaba adalah untuk menyediakan informasi mengenai aktiva, kewajiban, dan aktiva bersih dan informasi mengenai hubungan di antara unsur-unsur tersebut pada waktu tertentu. Kegiatan masjid diantaranya adalah melakukan pengelolaan zakat, infaq dan sedekah (ZIS). Standar akuntansi ZIS yang berlaku di Indonesia sekarang ini adalah Pernyataan Standar Akuntansi Keuangan (PSAK) Nomor 109 sebagai pedoman bagi organisasi pengelola zakat dalam pengakuan, pengukuran dan penyajian dan pengungkapan transaksi-transaksi ZIS (Rahman, 2015).

Hasil penelitian yang dilakukan oleh Andikawati (2014), menunjukkan bahwa Masjid Agung Anas Mahfudz dan Al-Huda di Lumajang belum menerapkan PSAK 109 dan PSAK 45 dalam laporan keuangannya, bentuk laporan keuangan masih sederhana. Namun setelah dilakukan rekonstruksi laporan keuangannya lebih cocok untuk disesuaikan dengan PSAK 109. Penyebab terhambatnya penerapan PSAK 109, karena sumber daya manusia dibidang akuntansi masih kurang sehingga mengalami kesulitan dalam penggolongan akun-akun sebagai dasar dalam penyusunan laporan keuangan. Demikian pula hasil penelitian yang dilakukan oleh Aldiansyah dan Lambey (2017), 
menunjukkan bahwa pada organisasi nirlaba yaitu yayasan juga masih sederhana meliputi buku penerimaan dan buku pengeluaran kas, buku rekapitulasi, dan bukan laporan keuangan yang ditetapkan sesuai dengan PSAK 45.

Berdasarkan hasil observasi yang dilakukan serta diskusi dengan pengurus Dewan Kemakmuran Masjid Al-Barokah di Jalan Loka Pala Raya, Kelurahan Cibodas, Kecamatan Cibodas, Kota Tangerang, Banten menunjukkan laporan keuangan kegiatan masjid masih dalam bentuk laporan saldo kas yang disampaikan pada setiap hari Jum "at. Laporan saldo kas bukanlah laporan keuangan tetapi hanya salah satu perkiraan yang ada pada laporan keuangan.

Hal ini perlu ditingkatkan kualitasnya sehingga para jamaah masjid dan para donatur memiliki kepercayaan yang tinggi terhadap pengurus Dewan Kemakmuran Masjid. Laporan keuangan perlu dapat dipertanggungjawabkan dan transparan. Kendala yang dihadapi oleh pengurus Dewan Kemakmuran Masjid, masih memiliki keterbatasan pengetahuan tentang seluk beluk laporan keuangan seperti jenis laporan keuangan dan para penggunanya. Disamping itu juga tidak memiliki keterampilan dalam menyusun laporan keuangan.

Berdasarkan analisis situasi tersebut, kegiatan pengabdian kepada masyarakat ini difokuskan untuk membantu menyelesaikan kesulitan yang dihadapi pengurus Dewan Kemakmuran Masjid dengan mengadakan pendidikan dan pelatihan teknik penyusunan laporan keuangan organisasi sosial keagamaan. Tujuan artikel ini untuk mengetahui pengaruh pendidikan dan pelatihan terhadap kemampuan peserta dalam menyusun laporan keuangan organisasi sosial keagamaan.

\section{TINJAUAN PUSTAKA \\ Pendidikan}

Pendidikan adalah proses untuk meningkatkan pengetahuan, sikap dan perilaku peserta didik tentang ilmu pengetahuan. Peserta didik akan diberikan pengetahuan tentang laporan keuangan meliputi: membangun kepercayaan masyarakat dan jenis laporan keuangan serta penggunanya.

Masjid merupakan tempat ibadah bagi umat muslim. Umumnya masjid dimiliki oleh masyarakat, sehingga penting para pengurus masjid yaitu Dewan Kemakmuran Masjid atau Takmir Masjid dipercaya oleh masyarakat. Untuk membangun kepercayaan masyarakat kepada pengurus masjid perlu komunikasi yang baik yang dilakukan oleh pengurus masjid kepada masyarakat. Komunikasi dapat dilakukan secara lisan maupun tulisan. Komunikasi lisan umumnya dilakukan setiap hari Jumat sebelum Khotib naik mimbar. Perwakilan pengurus menyampaikan perkembangan saldo kas selama 1 minggu terakhir. Ketika bulan Romadhon, umumnya juga disampaikan laporan perkembangan saldo kas harian yang disampaikan perwakilan pengurus sebelum ceramah Kultum Romadhon dimulai. Komunikasi secara tulisan umumnya juga dilakukan untuk menyampaikan perkembangan saldo kas yang seringkali dicantumkan di papan tulis yang ditaruh di bagian luar depan bangunan masjid. Komunikasi secara lisan maupun tulisan seringkali juga disampaikan oleh pengurus masjid tentang kegiatan-kegiatannya yang dapat diikuti oleh para jamaah.

Komunikasi yang dilakukan tersebut sebagai upaya untuk mempertanggungjawabkan kegiatankegiatan yang dilakukan pengurus secara transparan agar masyarakat tidak menaruh prasangka buruk terhadap pengurus. Masyarakat atau jamaah juga dapat melakukan pengawasan terhadap penyelenggaraan kegiatan yang dilakukan oleh pengurus dari sudut pandang kemanfaatan kegiatan, kualitas kegiatan, maupun kewajaran penggunaan dananya. Jika masyarakat menilai dari laporan yang disampaikan oleh pengurus dapat dipertanggungjawabkan dan transparan maka masyarakat memiliki kepercayaan yang baik terhadap pengurus dan sebaliknya. 
Masjid merupakan lembaga yang tujuannya adalah nirlaba. Di Indonesia organisasi nirlaba dalam menyampaikan laporan keuangannya diatur dalam PSAK Nomor 45. Berdasarkan PSAK ini laporan keuangan organisasi nirlaba meliputi laporan posisi keuangan, laporan aktivitas, laporan arus kas, dan catatan atas laporan keuangan (IAI, 2018). Laporan keuangan disusun dengan memperhatikan sifat pembatasan dana. PSAK Nomor 45 mendefinisikan sifat pembatasan dana sebagai berikut:

a. Pembatasan permanen yaitu pembatasan penggunaan sumber daya yang ditetapkan oleh penyumbang agar sumber daya tersebut dipertahankan secara permanen, namun organisasi diizinkan untuk menggunakan sebagian atau semua penghasilan atau manfaat ekonomi lainnya yang berasal dari sumber daya tersebut.

b. Pembatasan temporer yaitu pembatasan penggunaan sumber daya oleh penyumbang yang menetapkan agar sumber daya tersebut dipertahankan sampai dengan periode tertentu atau sampai dengan terpenuhinya keadaan tertentu.

c. Sumbangan terikat yaitu sumber daya yang penggunaannya dibatasi untuk tujuan tertentu oleh penyumbang. Pembatasan tersebut dapat bersifat permanen atau temporer.

d. Sumbangan tidak terikat yaitu sumber daya yang penggunaannya tidak dibatasi untuk tujuan tertentu oleh penyumbang.

Laporan keuangan merupakan gambaran singkat kondisi organisasi yang dinyatakan dalam bentuk uang. Menurut Harahap (2015) laporan keuangan menggambarkan kondisi keuangan dan hasil usaha suatu perusahaan pada saat tertentu atau jangka waktu tertentu.Umumnya pada organisasi bisnis, laporan keuangan meliputi: laporan laba rugi, laporan perubahan modal, neraca, laporan arus kas, dan catatan atas laporan keuangan (Kasmir, 2016).

Laporan laba rugi menyajikan hasil kinerja perusahaan selama satu periode. Kinerja perusahaan dapat dinilai dari pendapatan yang dihasilkan dikurangi dengan beban atau biaya dari kegiatan yang dilakukan. Kinerjanya dapat berupa laba, rugi maupun impas. Laba jika pendapatan melebihi biaya atau beban sedangkan rugi jika biaya atau beban lebih besar dari pendapatan dan impas jika pendapatan sama besarnya dengan biaya atau beban.

Laporan perubahan modal merupakan laporan yang menunjukkan perubahan jumlah modal selama periode tertentu. Saldo jumlah modal akhir periode bisa jadi mengalami perubahan dibandingkan akhir periode sebelumnya sebagai akibat adanya laba/rugi yang dialami perusahaan dalam periode tersebut. Laporan ini merupakan penjelas laporan neraca untuk akun modal.

Neraca menyajikan posisi keuangan perusahaan pada saat tertentu. Posisi saldo setiap akun pada saat tertentu yaitu tanggal pelaporan keuangan. Misalnya saldo kas, persediaan, tanah, gedung, mesin, peralatan, utang, modal sendiri pada tanggal 31 Desember 2019.

Laporan arus kas menunjukkan perubahan saldo kas akhir periode dibandingkan akhir periode sebelumnya sebagai akibat kegiatan operasi, pembiayaan maupun investasi. Kegiatan operasi berkaitan kegiatan merubah input menjadi keluaran yang merupakan kegiatan rutin perusahaan. Kegiatan pembiayaan berkaitan dengan kegiatan mendapatkan sumber pembiayaan dari pihak eksternal serta angsuran, pembayaran bunga dan dividen dan pelunasannya. Kegiatan investasi berkaitan dengan penanaman dana pada aktiva tetap serta penjualan aktiva tetap yang tidak dipergunakan lagi.

Catatan atas laporan keuangan dipandang perlu untuk mengetahui penjelasan secara terperinci dari setiap akun yang ada pada empat laporan keuangan lainnya. Akun yang ada pada laporan keuangan biasanya hanya terdiri dari beberapa kata bahkan kadang kala hanya satu kata serta jumlah saldo 
uangnya saja. Hal ini untuk mengetahui penjelasannya dapat membaca catatan atas laporan keuangan untuk akun yang ingin diketahuinya.

Organisasi Dewan Kemakmuran Masjid merupakan organisasi sosial keagamaan yang berorientasi pada kesejahteraan jamaahnya. Dalam laporan laba rugi bukan laba yang menjadi tujuan tetapi setidaknya dalam keadaan impas namun kegiatan yang dilakukan oleh Dewan Kemakmuran Masjid menjawab apa yang dibutuhkan dan diinginkan oleh jamaah sehingga jamaah lebih sejahtera. Berdasarkan alasan tersebut maka pada organisasi nirlaba sesuai dengan PSAK Nomor 45 laporan laba rugi diganti dengan laporan aktivitas. Laporan perubahan modal menjelaskan adanya perubahan dari awal ke akhir periode untuk modal sendiri yang biasanya berasal dari sumbangan dalam bentuk: zakat mal maupun infaq. Dalam PSAK Nomor 45, laporan ini tidak ditentukan. Neraca, dalam PSAK Nomor 45 disebut sebagai laporan posisi keuangan. Pada laporan ini disajikan saldo harta, utang, maupun modal sendiri pada tanggal tertentu. Harta pada masjid umumnya dalam bentuk kas, perlengkapan, tanah, gedung, peralatan sedangkan hutang bisanya berupa hutang jangka pendek seperti hutang gaji untuk penjaga masjid, biaya listrik yang belum dibayar dan modal sendiri berupa sumbangan para jamaah atau donatur. Laporan arus kas menyajikan penerimaan dan pengeluaran kas untuk kegiatan operasi, pembiayaan dan investasi. Bagi masjid yang sudah berdiri dengan baik, maka arus kas yang terjadi lebih banyak dari kegiatan operasi dan pembiayaan.

Laporan keuangan diperlukan untuk mengambil keputusan. Para penggunanya dapat dikelompokkan menjadi dua yaitu pihak internal dan eksternal. Pihak internal yaitu pihak pengelola organisasi. Pihak eksternal meliputi pemilik (para jamaah masjid), kreditur, pemerintah dan sebagainya. Para pengelola perlu mengetahui laporan keuangan untuk mengetahui apakah kinerjanya mengalami perbaikan, penurunan ataukah tidak ada perubahan dibandingkan periode sebelumnya. Pihak eksternal memerlukan laporan keuangan untuk mengambil keputusan apakah akan memberikan sumbangan ataukah tidak, mendukung dan mengikuti kegiatan yang dilakukan oleh pengurus ataukah tidak.

\section{Pelatihan}

Pelatihan penyusunan laporan keuangan pada organisasi sosial keagamaan akan diawali mendata aset Dewan Kemakmuran Masjid, hutang maupun sumber sumbangan. Selanjutnya mendata jenisjenis biaya yang menjadi beban organisasi. Langkah berikutnya menetapkan nomenklatur untuk akun yang disajikan dalam laporan keuangan. Berdasarkan nomenklatur tersebut dapat disusun nama akun pada setiap laporan keuangan. Laporan keuangan yang utama adalah neraca atau laporan posisi keuangan sedangkan laporan keuangan yang lainnya merupakan pendukung neraca.

Selanjutnya yang dilakukan adalah menyusun laporan posisi keuangan awal periode. Oleh karena transaksi yang dilakukan pada organisasi sosial keagamaan adalah tunai maka penting untuk menyusun laporan penerimaan dan pengeluaran kas secara terperinci. Laporan ini merupakan laporan arus kas. Dari laporan penerimaan dan pengeluaran kas ini dapat disusun lebih lanjut untuk mengoreksi posisi pada setiap perkiraan yang ada pada laporan posisi keuangan per tanggal pelaporan berikutnya. Pada organisasi sosial keagamaan tidak memandang laporan laba rugi sebagai laporan yang penting karena orientasinya sosial, dan berdasarkan PSAK 19, laporan tersebut disebut laporan aktivitas.

\section{METODE PELAKSANAAN}

Kegiatan pengabdian masyarakat dilakukan mulai Februari 2020 sampai dengan Juli 2020. Populasi kegiatan atau khalayak sasarannya yaitu pengurus dan calon pengurus DKM dan jamaah Masjid Al-Barokah, Jl Lokapala Raya, RW 08, Kelurahan Cibodas, Kecamatan Cibodas, Kota 
Tangerang, Banten. Sedangkan yang menjadi sampel kegiatan sebanyak 32 orang. Metode penyampaian materi dilakukan dengan ceramah, tanya jawab dan latihan. Sebelum pelaksanaan pelatihan, dilakukan pretest untuk mengetahui pengetahuan dan keterampilan peserta tentang teknik penyusunan laporan keuangan organisasi sosial keagamaan khususnya masjid. Setelah selesai pelatihan dilakukan posttest dengan menggunakan pertanyaan yang sama untuk mengetahui ada tidaknya pengaruh pendidikan dan pelatihan terhadap pengetahuan dan keterampilan peserta dalam menyusun laporan keuangan. Alat analisis statistik yang digunakan yaitu uji beda wilcoxon matched pairs test.

\section{Tahap Kegiatan PKM}

Kegiatan secara garis besar terbagi dalam 6 tahap dengan rincian kegiatan tertera dalam Tabel 1 berikut ini.

\section{Tabel 1}

\section{Jadwal Pelaksanaan Kegiatan}

\begin{tabular}{lll}
\hline No. & Waktu & Kegiatan \\
\hline 1. & Awal Januari 2020 & Diskusi dengan perwakilan mitra/ khalayak sasaran \\
2. & Januari 2020 & Menyusun dan menyampaikan proposal kegiatan \\
3. & Awal Pebruari 2020 & Koordinasi dengan mitra/khalayak sasaran tentang pelaksanaan kegiatan \\
4. & Maret-Mei 2020 & Penyusunan materi pelatihan \\
5. & Juni-Juli 2020 & Pelaksanaan kegiatan \\
6. & Akhir Juli 2020 & Laporan pelaksanaan kegiatan \\
\hline
\end{tabular}

\section{HASIL PELAKSANAAN KEGIATAN DAN PEMBAHASAN}

\section{Hasil Pelaksanaan Kegiatan}

a. Analisis Pelaksanaan Pelatihan

Pelatihan dapat terlaksana dengan baik berkat kerjasama Tim PKM Universitas Tarumanagara dengan Pengurus BKM Al Barokah. Dengan kerjasama tersebut, maka mempermudah TIM PKM Universitas Tarumanagara dalam melaksanakan pendidikan dan pelatihan. Pengurus DKM mempersiapkan peserta, tempat, fasilitas pelatihan sedangkan TIM PKM Universitas Tarumanagara menyampaikan materi pendidikan dan pelatihan beserta kelengkapannya. Dari sisi organisasi pelaksanaan pendidikan dan pelatihan tidak mudah dilakukan karena adanya pandemi Covid 19.

Pelaksanaan pendidikan dan pelatihan dilakukan pada Minggu, 12 Juli 2020 di Masjid Al-Barokah Jalan Loka Pala Raya, RW 08, Kelurahan Cibodas, Kecamatan Cibodas, Kota Tangerang, Banten. Kegiatan dimulai dengan mendata peserta, selanjutnya peserta diberikan pretest untuk mengetahui pengetahuan dan keterampilannya tentang teknik penyusunan laporan keuangan organisasi sosial keagamaan. Selanjutnya TIM PKM Universitas Tarumanagara memberikan presentasi, tanya jawab dan latihan. Kegiatan diakhiri dengan posttest untuk mengetahui dampak pendidikan dan pelatihan terhadap pengetahuan dan keterampilan peserta. Berdasarkan evaluasi pelaksanaan kegiatan pelatihan, maka kegiatan pelatihan cenderung memakan waktu lebih lama dari seharusnya karena tingkat kerumitan materi yang tinggi.

\section{b. Analisis Statistik Deskriptif}

Tabel statistik deskriptif menyajikan demografi responden yang mengikuti kegiatan pendidikan dan pelatihan. Tabel 2 menyajikan gambaran responden meliputi umur, gender dan status perkawinan. Rata rata umur responden antara 20 sampai dengan 25 tahun, dengan gender semuanya pria dan mayoritas statusnya adalah tidak kawin atau belum menikah. 


\section{Tabel 2}

\section{Statistik Deskriptif Demografi Responden}

\begin{tabular}{|c|c|c|c|c|c|}
\hline & $\mathbf{N}$ & Minimum & Maximum & Mean & Std. Deviation \\
\hline Umur & 32 & 1,00 & 4,00 & 2,4375 & 1,07576 \\
\hline Gender & 32 & 1,00 & 1,00 & 1,0000 &, 00000 \\
\hline Status_nikah & 32 & 1,00 & 2,00 & 1,3750 & ,49187 \\
\hline Valid N (listwise) & 32 & & & & \\
\hline
\end{tabular}

\section{Catatan.}

(a) Umur : 1 (15 s.d 20 tahun), 2 (di atas 20 s.d 25 tahun), 3 (di atas 25 s.d 40 tahun), 4 (di atas 40 tahun);

(b) Gender:1 (pria), 2 (wanita);

(c) Status :1 (kawin), 2 (tidak kawin).

Tabel 3 menyajikan hasil pretest untuk variabel pendidikan meannya sebesar 3,3938 (mendekati 3 yang berarti netral) sedangkan hasil posttestnya sebesar 4,2250 (mendekati 4 yang berarti setuju). Hal ini menandakan adanya pengaruh pendidikan terhadap peningkatan pengetahuan peserta tentang penyusunan laporan keuangan. Demikian pula hasil pretest untuk variabel pelatihan menyusun laporan keuangan dengan mean sebesar 2,7688 dan setelah postest meannya menjadi 3,7438 (mendekati 4 yang berarti setuju). Hal ini menandakan bahwa pelatihan dapat meningkatkan keterampilan peserta untuk penyusunan laporan keuangan organisasi sosial keagamaan.

\section{Tabel 3}

Statistik Deskriptif Pendidikan dan Pelatihan Menyusun Laporan Keuangan

\begin{tabular}{|c|c|c|c|c|c|}
\hline & $\mathbf{N}$ & Minimum & Maximum & Mean & Std. Deviation \\
\hline $\begin{array}{l}\text { Nilai Pretest } \\
\text { Pendidikan }\end{array}$ & 32 & 2,60 & 4,20 & 3,3938 & ,34635 \\
\hline $\begin{array}{l}\text { Nilai Posttest } \\
\text { Pendidikan }\end{array}$ & 32 & 3,60 & 4,80 & 4,2250 & ,31212 \\
\hline Nilai Pretest Pelatihan & 32 & 1,20 & 3,60 & 2,7688 & ,49542 \\
\hline $\begin{array}{l}\text { Nilai Posttest } \\
\text { Pelatihan }\end{array}$ & 32 & 3,00 & 4,20 & 3,7438 & ,29723 \\
\hline Valid N (listwise) & 32 & & & & \\
\hline
\end{tabular}

\section{a. Hasil Uji Wilcoxon Matched Pairs Test}

Untuk mengetahui pengaruh pendidikan dan pelatihan terhadap kemampuan responden untuk menyusun laporan keuangan sebelum dan setelah pendidikan dan pelatihan maka dilakukan uji Wilcoxon Match Pairs Test. Uji ini mensyaratkan data indikator dari variabel memiliki skala ordinal, dan data yang diperoleh memenuhi persyaratan tersebut. Tabel 4 menunjukkan hasil uji beda pretest dan posttest untuk variabel penelitian.

\section{Tabel 4}

Wilcoxon Signed Ranks Test

\begin{tabular}{|c|c|c|c|c|}
\hline & & $\mathrm{N}$ & Mean Rank & Sum of Ranks \\
\hline \multirow{4}{*}{$\begin{array}{l}\text { Nilai Postest - Nilai Pretest } \\
\text { Pendidikan Penyusunan } \\
\text { laporan Keuangan }\end{array}$} & Negative Ranks & $0^{\mathrm{a}}$ & ,00 & ,00 \\
\hline & Positive Ranks & $32^{\mathrm{b}}$ & 16,50 & 528,00 \\
\hline & Ties & $0^{\mathrm{c}}$ & & \\
\hline & Total & 32 & & \\
\hline \multirow{4}{*}{$\begin{array}{l}\text { Nilai Postest - Nilai Pretest } \\
\text { Pelatihan Penyusunan Laporan } \\
\text { Keuangan }\end{array}$} & Negative Ranks & $0^{\mathrm{d}}$ & , 00 & ,00 \\
\hline & Positive Ranks & $32^{\mathrm{e}}$ & 16,50 & 528,00 \\
\hline & Ties & $0^{f}$ & & \\
\hline & Total & 32 & & \\
\hline
\end{tabular}




\begin{tabular}{|c|c|c|}
\hline \multicolumn{3}{|l|}{ b. Nilai Postest > Nilai Pretest } \\
\hline \multicolumn{3}{|l|}{ c. Nilai Postest $=$ Nilai Pretest } \\
\hline \multirow{2}{*}{\multicolumn{3}{|c|}{$\begin{array}{l}\text { d. Nilai Postest }<\text { Nilai Pretest } \\
\text { e. Nilai Postest }>\text { Nilai Pretest }\end{array}$}} \\
\hline & & \\
\hline \multicolumn{3}{|l|}{ f. Nilai Postest $=$ Nilai Pretest } \\
\hline \multicolumn{3}{|c|}{ Test Statistics $^{a}$} \\
\hline & Nilai Postest - Nilai Pretest & Nilai Postest - Nilai Pretest \\
\hline & Pendidikan Penyusunan laporan & Pelatihan Penyusunan \\
\hline & Keuangan & Laporan Keuangan \\
\hline $\mathrm{Z}$ & $-4,963^{\mathrm{b}}$ & $-4,969^{\mathrm{b}}$ \\
\hline Asymp. Sig. (2-tailed) &, 000 &, 000 \\
\hline \multicolumn{3}{|c|}{ a. Wilcoxon Signed Ranks Test } \\
\hline b. Based on negative ranks. & & \\
\hline
\end{tabular}

Berdasarkan Tabel 4, hasil test statistics untuk pretest-posttest pendidikan menunjukkan asymp. sig. (2-tailed) sebesar 0,000 lebih rendah dari dari 0,05, hal ini berarti terdapat perbedaan yang signifikan pengetahuan responden tentang penyusunan laporan keuangan sebelum dan setelah pendidikan. Demikian pula hasil test statistics untuk pretest-posttest keterampilan menyusun laporan keuangan menunjukkan asymp. sig. (2-tailed) sebesar 0,000 lebih rendah dari 0,05 hal ini berarti terdapat perbedaan yang signifikan keterampilan penyusunan laporan keuangan sebelum dan setelah pelatihan.

\section{Pembahasan}

Berdasarkan hasil uji statistik tersebut menunjukkan terdapat perbedaan antara hasil postest dengan hasil pretest untuk pengetahuan dan keterampilan responden terkait sebelum dan sesudah pendidikan dan pelatihan. Dengan demikian kegiatan pendidikan dapat meningkatkan pengetahuan peserta dalam menyusun laporan keuangan. Demikian pula kegiatan pelatihan dapat meningkatkan keterampilan peserta dalam menyusun laporan keuangan. Berdasarkan pembahasan tersebut, maka kegiatan ini dapat membantu memecahkan masalah yang dihadapi Dewan Kemakmuran Masjid dalam menyusun laporan keuangan.

\section{KESIMPULAN DAN SARAN}

Berdasarkan permasalahan dan pembahasan tersebut maka dapat ditarik beberapa kesimpulan sebagai berikut. Kegiatan pendidikan dan pelatihan dapat terlaksana berkat kerjasama yang baik antara Tim PKM Universitas Tarumanagara dengan pengurus DKM Masjid Al-Barokah, Cibodas, Kota Tangerang, Banten. Pendidikan yang dilakukan dapat meningkatkan pengetahuan peserta tentang pentingnya laporan keuangan yang transparan dan akuntabel bagi para jamaah, maupun donatur. Pelatihan yang dilakukan dapat meningkatkan keterampilan responden tentang tata cara penyusunan laporan keuangan khususnya untuk memenuhi ketentuan PSAK 45.

Berdasarkan kesimpulan tersebut, maka dapat disarankan sebagai berikut. Bagi pengurus masjid penting untuk melakukan pendidikan dan pelatihan kepada calon pengurus masjid yang belum mendapatkan pendidikan dan pelatihan cara menyusun laporan keuangan masjid. Melalui tim dosennya, perguruan tinggi dapat menyelenggarakan kegiatan pendidikan dan pelatihan cara menyusun laporan keuangan organisasi sosial keagamaan pada cakupan yang lebih luas, karena hampir semua masjid baru menyampaikan laporan keuangan berupa laporan penerimaan dan pengeluaran kas. 


\section{Ucapan Terima Kasih}

Kegiatan PKM ini dapat terlaksana karena adanya kerjasama antara Universitas Tarumanagara dengan komponen masyarakat. Oleh karena itu, izinkan kami mengucapkan banyak terima kasih kepada:

a. Universitas Tarumanagara melalui Ketua LPPM dan para stafnya yang telah memfasilitasi dan mendanai kegiatan PKM.

b. DKM Masjid Al-Barokah Jalan Loka Pala Raya, RW 08, Kelurahan Cibodas, Kecamatan Cibodas, Kota Tangerang, Banten 15138 melalui Ketua dan pengurus lainnya yang mengundang peserta, menyediakan tempat serta akomodasi lainnya sehingga kegiatan PKM dapat berjalan dengan lancar.

Tanpa kerjasama yang baik dengan mereka maka kami tidak dapat melaksanakan kegiatan PKM di tengah pandemi Covid 19 ini. Semoga kegiatan yang telah diikuti dapat membawa manfaat bagi kemakmuran masjid tersebut.

\section{REFERENSI}

Aldiansyah, \& Lambey, L. (2017). Penerapan PSAK No. 45 revisi tahun 2015 pada Yayasan Madrasah Ibtidaiyah Baitul Makmur Kota Kotamobagu. Jurnal Accountability, 6(1), $92-$ 102. https://doi.org/10.32400/ja.16031.6.1.2017.92-102

Andikawati, D. (2014). Laporan keuangan lembaga masjid (Studi kasus pada lembaga Masjid Agung Anas Mahfudz dan Al-Huda) [Skripsi, Universitas Jember]. http://repository.unej.ac.id/bitstream/handle/123456789/57995/DESY\%20ANDIKAWATI \%20-\%20080810301006_1.pdf; sequence $=1$

Harahap, S.S. (2015). Analisis kritis atas laporan keuangan. Rajawali Press.

Ikatan Akuntan Indonesia. (2018). Standar akuntansi keuangan. Ikatan Akuntan Indonesia.

Kasmir. (2016). Analisis laporan keuangan. RajaGrafindo Persada.

Rahman, T. (2015). Akuntansi zakat, infaq, sedekah (PSAK 109): Upaya peningkatan transparansi dan akuntabilitas Organisasi Pengelola Zakat (OPZ). Jurnal Muqtasid, 6(1), 141-164. https://doi.org/10.18326/muqtasid.v6i1.141-164 